\title{
The potential leaves extract of Piper methysticum (piperaceae) as botanical insecticide against Crocidolomia pavonana (f.) larvae mortality (lepidoptera:crambidae)
}

\author{
Johana A. Mendes ${ }^{1}$, Nurhening Y. Ekowati ${ }^{1}$, Diana S. Susanti ${ }^{1}$, Jefri Sembiring ${ }^{1}$, Andri Prasetia ${ }^{1}$, and Rosmala \\ Widijastuti $^{1}$ \\ ${ }^{1}$ Department of Agrotechnology, Agriculture of Faculty, Musamus University, Merauke - Indonesia
}

\begin{abstract}
The application of various agricultural technologies such as the using by fertilizers, pesticides, and clearing land will have resulted changes in the ecosystem. Using by insecticides can gived negative impact such as causing resistance, resurgensy and environmental pollution due to residues that can last a long time and are difficult to decompose, because it have compound among other carbon, chlorin, and hidrogen. Piper methysticum (Piperaceae) is one of plant which are used for medicine and social-cultural activitiy by Merauke community, Papua. Meanwhile, Crocidolomia pavonana (Lepidoptera:Crambidae) is one of major pest on the family Brassicaceae plants. The objective of this research was to effectiveness test for simple extract $P$. methysticum leaves as a botanical insecticide against $C$. pavonana larvae (Lepidoptera: Crambidae). The insecticide activities were assessed including mortality. Mortality tests using leaf wet method were seven concentrations $(5 \mathrm{gr} / 100 \mathrm{ml}, 10 \mathrm{gr} / 100 \mathrm{ml}, 15 \mathrm{gr} / 100 \mathrm{ml}, 20 \mathrm{gr} / 100 \mathrm{ml}, 25 \mathrm{gr} / 100 \mathrm{ml}, 30 \mathrm{gr} / 100 \mathrm{ml}, 35 \mathrm{gr} / 100 \mathrm{ml}) \mathrm{plus}$ control. Each treatment was introduced ten $C$. pavonana instar $2^{\text {nd }}$ larvaes and replicated five times. The results showed that extract $P$. methystichum leaves gave $22 \%$ mortality at $35 \mathrm{gr} / 100 \mathrm{ml}$ water.
\end{abstract}

Keywords: botanical insecticide; mortality; Piper methysticum

\section{INTRODUCTION}

The application of various agricultural technologies such as the using by fertilizers, pesticides, and clearing land will have resulted changes in the ecosystem. Pesticide is a chemical compound that can affecting the physiology and behavior for organism disturbing plant. Class of pesticide often used by farmer is a insecticide. Using by insecticides can gived negative impact such as causing resistance, resurgensy and environmental pollution due to residues that can last a long time and are difficult to decompose, because it have compound among other carbon, chlorin, and hidrogen.

Botanical insecticide is an active insecticide with a compound derived from a secondary metabolite of plants (Dadang and Prijono, 2008)[4]. Botanical insecticide is now widely developed potential because it has advantages such as easily degraded in nature so as not to leave toxins in the environment, can insect feeding inhibit until to that death of pests and have low toxicity for plants. Some plants that have been known for their effectiveness as a botanical insecticide from piperaceae family include javanese chilli (Piper retrofractum) for Helopeltis antonii Sign. (Hemiptera: Miridae) (Indriati et al., 2015)[7], larvacidal of betel leaves extract (Piper betle L.) for Aedes aegypti L larvae (Aulung et al., 2010) [2], and according to Syahroni and Prijono (2013)[14] about insecticidal activity of Piper aduncum L fruits extract (Piperaceae) and Sapindus rarak DC. (Sapindaceae) and it's mixture against $C$. pavonana larvae (Lepidoptera: Crambidae). Piper methysticum (Piperaceae) is one of the plant used of the Merauke community as a drug or used as a main of plant in socio-cultural such as in marriage, death or peace events (Kameubun, 2003; Suharno et al., 2016) [8],[13].

Part of plant P. methysticum is also used as a medicine, where the root is used as a cough and wound medicine and part of the leaf is used as a wound for insect bites and puncture of several species of fish. Based on result of research Agusta et al., (1998)[1], leaves of $P$. methysticum extract with three types of solvents showed several chemical components such as n-hexane extract consisting of 20 components, methanol extract consists of 14 components and chlorophomic extract consists of 16 components. Meanwhile, according to Lestari et al., (2014)[9] that the extract of n-hexane leaf of $P$. methysticum showed insecticidal activity as a feeding inhibiton of $11.69 \%$ until to $85.54 \%$, heavy inhibiton of $34.75 \%$ until to $81.88 \%$ and mortality against

*Corresponding author: mendesjoanna613@gmail.com 
Plutella xylostella larvae about $63,33 \%$ with LC50 4,4047 ppm.

Crocidolomia pavonana L. (Lepidoptera : Crambidae) is one of the main pests of Brassicaceae families such as cabbage, cauliflower, broccoli and petsay. This pests can attack on the cabbage leaves, then the larger larvae will attack the part of crop, so it can reduce the quality of crop (Badjo et al., 2015)[3]. Control measures under taken by farmers to reduce the population of pests are using chemical control, but the measures do not have major effect in suppressing the pests population of $C$. pavonana. Chemical control such as the use of synthetic insecticides into control measures used by some parties, easy in application and able to efficiently the time, cost and labor (Dadang and Prijono, 2008)[4]. However, improper use and high frequency of spraying can lead to such things as pests resistance, natural enemy death and environmental pollution. Several studies have showed the use of synthetic insecticides for farmers or have recidual contained in products that can be directly among others is according to Yuantari MGC et al., (2015) [15] about risks that occur when the farmer applying high pesticides.

Pesticides can penetrate in the body through by the skin, breathing and digestion when farmers carry, store, mixed, and spraying or spray cleaning after used. Herdariani (2014) [6], explain about residual detected of chlorpyrophic pesticide in ready to eat cabbage are $1 \mathrm{mg} / \mathrm{kg}$ below the BMR, but if consumed continuously may pose a risk to the body. Negative impact to the environment can be showed based on research results from Regita DS., et al (2016) [12] about using and pesticide handling by 55 farmers onion in Wanasari village, Wanasari Distric amount $69,1 \%$ and $50,9 \%$ that not good classified. Therefore, the unwise use of pesticides can caused environmental damage, so was a study make to determine the potential of $P$. methysticum leaves extract as a botanical insecticide against $C$. pavonana larvae mortality that serve as alternative control for this pests controling and than decrease negative impact used for pesticide synthetic.

\section{METHODOLOGY}

Research was conducted in the laboratory of Department of Agrotechnology, Faculty of Agriculture, Musamus University from September until Desember 2017.

\subsection{Multiplication of Crocidolomia pavonana}

The test insect come from vegetabels farm that located in Martadinata region, Merauke Districts, Papua. Multiplication procedure the test insect using by Prijono and Hasan (1992)[11] methods. The larvae are given cabbage feed and honey $10 \%$ to adults which is applied to cotton and placed above the insect cage. Mustard leaf used as medium for female lay eggs. Egg groups will be collected and left to hatch. Larvae $2^{\text {nd }}$ instare used in the test.

\subsection{Extraction process}

Plant material that used as a source of extract is $P$. methysticum leaveas (Piperaceae) that come from Wasur Village, Merauke District, Papua. Extraction process using by immersion method. Extracted material using mortal and then soaked in $100 \mathrm{ml}$ of water plus 0,1 gram detergen. The result of immersion will be filter and extract ready for use.

\subsection{Method}

Testing using leaf wet method. The extract was tested at seven concentrations plus control. Level of concentration used is $5 \mathrm{gr} / 100 \mathrm{ml}$ water, $10 \mathrm{gr} / 100 \mathrm{ml}$ water, $15 \mathrm{gr} / 100 \mathrm{ml}$ water, $20 \mathrm{gr} / 100 \mathrm{ml}$ water, 25 $\mathrm{gr} / 100 \mathrm{ml}$ water, $30 \mathrm{gr} / 100 \mathrm{ml}$ water and $35 \mathrm{gr} / 100 \mathrm{ml}$ water and repeated five times. Insects test of 10 larvae instare $2^{\text {nd }}$ and observations were made after 24,48 and 72 hours after treatment for dead larvae count. Counting mortality of $C$. pavonana larvae using formula :

$$
P=\frac{a}{b} \times 100 \%
$$

Information :

$P=$ Mortality $(\%)$

$a=$ The number of dead test insect

$b=$ The number of insects tested

mortality data will be analysis probit using POLO program (LeOra Sofware).

\section{RESULT AND DISCUSSION}

Testing of extract $P$. methysticum leave using leaf wet method effective of causing mortality in the amount of $6 \%$ until $12 \%$ starting from $10 \mathrm{gr} / 100 \mathrm{ml}$ water until $35 \mathrm{gr} / 100 \mathrm{ml}$ water concentrations at observation 24 HAT. Meanwhile, on $5 \mathrm{gr} / 100 \mathrm{ml}$ water concentration not caused mortality. The observation of 48 HAT, increase mortality to occur 15 $\mathrm{gr} / 100 \mathrm{ml}$ water until $35 \mathrm{gr} / 100 \mathrm{ml}$ water concentrations of causing mortality amount of $2 \%$ and control treatment not caused of mortality (Fig.1).

Several active compounds of $P$. methysticum have been identificated is cavalactone, pyrones, flavonoids and alchaloids. The compound belong to the cavalactone are cavain, dihydrocavain, methysticin and dihydromethysticin, while the cavain compound is considered largest constituent compound of $P$. methysticum extract. 


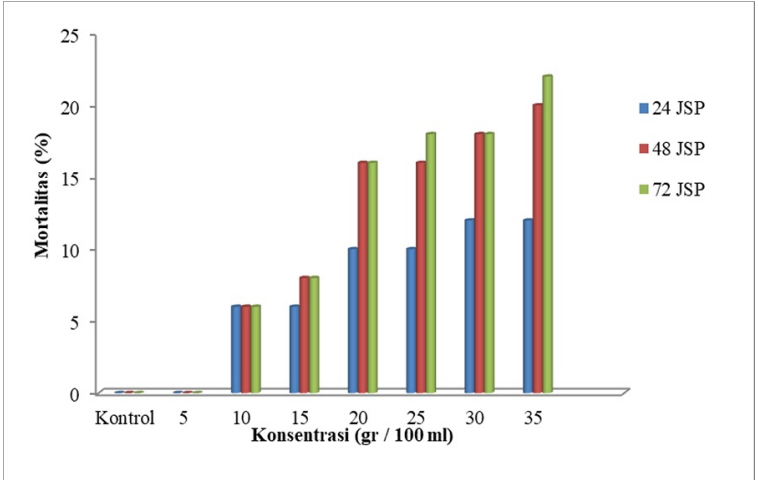

Fig. 1. Mortality of $C$. pavonana larvae caused leaves $P$. methysticum extract (Piperaceae) treatment.

The Clinical indication about consumption of $P$. methysticum to some extent can treat anxiety, social anxiety, anxiety generalized disorder, stress, mood swings and insomnia (Ernst, 2007)[5]. According to Lestari et al., (2014)[9], crude extract P. methysticum using n-hexane and ethyl acetate solvents capable of causing the death of Plutella xylostella larvae respectively $85,19 \%$ and $80,77 \%$ at 4000 ppm concentration. Thus the death of $C$. pavonana larvae on mortality test of leaves $P$. methysticum extract was suspected to be caused by the work of the identified compounds.

Table 1. Parameter of probit regression correlation of $P$. methysticum extract concentration with mortality of C. pavonana larvae

\begin{tabular}{|c|c|c|c|}
\hline $\begin{array}{c}\text { Time } \\
\text { of } \\
\text { Observ } \\
\text { ation }\end{array}$ & $b \pm \mathrm{SE}^{*}$ & $\begin{array}{c}\mathrm{LC}_{50} \\
(\mathrm{SK} \\
95 \%)(\%)^{*}\end{array}$ & $\begin{array}{c}\mathrm{LC}_{95} \\
(\mathrm{SK} \\
95 \%)(\%)\end{array}$ \\
$\begin{array}{c}\text { (HAT) } \\
*\end{array}$ & & & \\
\hline 24 & $1.20 \pm 0.46$ & 297.78 & 6980.90 \\
$(-)$ & $-)$ \\
\hline 48 & $1.70 \pm 0.44$ & $\begin{array}{c}97.30 \\
(56.43-\end{array}$ & $\begin{array}{c}900.83 \\
(250.31- \\
\end{array}$ \\
\hline 72 & $1.79 \pm 0.45$ & $\begin{array}{c}87.00 \\
(53.29-\end{array}$ & $\begin{array}{c}720.02 \\
(224.58-\end{array}$ \\
& & $341.95)$ & $21496.00)$ \\
\hline
\end{tabular}

$* b=$ Slope of regression; $S E=$ Standar Error; $H A T=$ Hour After Treatment.

The activities of extract can be illustrated based on probit regression and showing the relationship between of concentration of $C$. pavonana and larvae mortality (Table 1). Based on value of LC50 at SK $95 \%$, the amount concentration of leaves $P$. methysticum extract required to kill $50 \%$ of test insects on observation to 24 HAT was $297,8 \%$, but decreased the concentration down to 72 HAT to $87,00 \%$. Meanwhile, concentration in LC95 showed higher concentration values to kill $95 \%$ of test insects.
The slope of regression $(b)$ of $P$. methysticum extract on observations time of 72 HAT. The result show the concentration of extract at a certain amount can increase mortality of $C$. pavonana larvae.

\section{CONCLUSION}

The potential leaf of $P$. methysticum extract is caused the mortality of C. pavonana larvae of $22 \%$ at a concentration of $35 \mathrm{gr} / 100 \mathrm{ml}$ water using leaf wet method.

\section{REFERENCES}

[1] Agusta A, Jamal Y, Chairul. Analisis Komponen Kimia Daun Wati (Piper methysticum Forst). Berita Biologi. 4, 2 and 3 (1998).

[2]Aulung A, Christiani, Ciptaningsih. Daya larvasida ekstrak daun sirih (Piper betle L) terhadap mortalitas larva Aedes aegypti L. Majalah Kedokteran FK UKI. 17(1):7-14 (2010)

[3] Badjo R, Rante CS, Meray ERM, Assa BH, Dien MF. Serangan hama ulat krop (Crocidolomia pavonana (F.)) pada tanaman kubis (Brassica oleracea var. capitata L.) di Kelurahan Kakaskasen II Kecamatan Tomohon Utara, Kota Tomohon. E-Journal Unsrat. https://ejournal.unsrat.ac.id (2015).

[4] Dadang, Prijono D. Insektisda Nabati Prinsip, Pemanfaatan, dan Pengembangan. Departemen Proteksi Tanaman. IPB. Bogor (ID) (2008).

[5] Ernst.E. A re-evaluation of kava (Piper methysticum). British Journal of Clinical Pharmacology (2007) in Suharno, Tanjung RHR, Sufaati S, Agutini V. Wati (Piper methysticum) Medicinal Plant : The Ethnobiological and Ethnomedicinal Values of the Marind Tribe in Merauke, Papua, Indonesia. J. Biodiversitas. 12, 2 (2016)

[6] Herdariani E. Identifikasi Residu Pestisida Klorpirifos dalam Sayuran Kol Mentah dan Kol Siap Santap. Jurnal MKMI. 154-159 (2014).

[7] Indriati G, Dadang, Prijono D. Aktivitas insektisida ekstrak buah cabai jawa (Piper retrofractum) terhadap Heliopeltis antonii (Hemiptera: Miridae). J Littri. 21,1 (2015).

[8] Kameubun. KMB. Aspek Botani dan Etnobotani Wati (Piper methysticum Forst.) dalam Kehidupan Suku Marind Kabupaten Merauke, Papua. [Tesis]. Bogor (ID) : Institut Pertanian Bogor (2003).

[9] Lestari MS, Himawan T, Abadi AL, Retnowati R. Potensi ekstrak Piper methysticum (Piperaceae) sebagai insektisida botani untuk pengendalian hama Plutella xylostella. J. Sains dan Matematika. 3,1( 2014)

[10] Park JS, Lee SC, Shin BY, Lee, Ahn YJ. Larvicidal and antifeeding activities of oriental medicinal plant extract four species of forest 
insect pest. Appl Entomol Zool. 32(4):601608. (1997).

[11] Prijono D, Hassan E. Life cycle and demography of Crocidolomia binotalis Zell. (Lepidoptera: Pyralidae) on broccoli in the laboratory. J Trop Agric Indones. 4 (1992).

[12] Regita DS, Yusniar HD, Nikie AYD. Hubungan Pengunaan dan Penanganan Pestisida Pada Petani Bawang Merah Terhadap Residu Pestisida dalam Tanah di Lahan Pertanian Dewa Wanasari Kecamatan Wanasari Kabupaten Brebes. Jurnal Kesehatan Masyarakat. 4,3 : 879-887 (2016).

[13] Suharno, Tanjung RHR, Sufaati S, Agutini V. Wati (Piper methysticum) Medicinal Plant :
The Ethnobiological and Ethnomedicinal Values of the Marind Tribe in Merauke, Papua, Indonesia. J. Biodiversitas. 12, 2. (2016).

[14] Syahroni YY, Prijono D. Aktivitas insektisida ekstrak buah Piper aduncum L. (Piperaceae) dan Sapindus rarak DC. (Sapindaceae) serta campurannya terhadap larva Crocodolomia pavonana (F.) (Lepidoptera: Crambidae). J Entomol Indones. 10,1:39-50.( 2013)

[15] Yuantari MGC, Widianarko B, Sunoko H.R. Analisis Risiko Pajanan Pestisida Terhadap kesehatan petani. J. Kemas.10,2:239-245 (2015). 